\title{
The Effect of Financial Ratio, EVA and Exchange Rate on Stock Return in Fishery Subsector
}

\author{
Andhi Reza $\mathrm{A}^{1, *}$, Heny K Daryanto ${ }^{2}$ and Hendro Sasongko ${ }^{3}$ \\ ${ }^{1}$ Sekolah Bisnis Institut Pertanian Bogor \\ (Bogor, Indonesia) \\ ${ }^{2}$ Sekolah Bisnis Institut Pertanian Bogor \\ (Bogor, Indonesia) \\ ${ }^{3}$ Sekolah Bisnis Institut Pertanian Bogor \\ (Bogor, Indonesia) \\ *Corresponding author's email: andhiprivatesmail [AT] gmail.com
}

\begin{abstract}
The purpose of this study is to find the relationship between financial ratio and EVA with fishery subsector stock return in Indonesia. The finacial ratio used in this study are Current Ratio, Debt to Equity Ratio (DER), and Return on Equity (ROE) who are represent liquidity, solvency, and companies profitability. Other factor that has to be measured is Economic Value Added (EVA). EVA has been used for years to measure companies performance, however there are a lot of diferent result among researcher around the world about EVA as the best finacial peformance indicator for companies and can affect companies stock return. One of the macroeconomic factor that expected to have significant effect on stock return is exchange rate. The activity of fishery industries are circle around export and import, therefore exchange rate are expected to be the macroeconmic factor that could affect stock return. The result of this research shown that there are no significant relationship between finacial ratio, EVA, and exchange rate with stock return in fishery subsector.
\end{abstract}

Keywords - Economic Value Added, Financial Ratio, Exchnage Rate, Stock Return

\section{INTRODUCTION}

The entire manuscript, including mathematical equations, tables, and figures Indonesian stock market showing its growth by the end of 2015. According to Financial Services Authority (FSA) there is an improvement in terms of number of transaction, number of listed companies, and Indonesia Composite Index. This growth can be used as an oportunity for a new investor to invest in Indoseian stock market. One of the sector that supposed to be the superior in Indonesian stock market is fishery sector, as a maritime country, Indonesia has a lot advantages in fishery sector. However the fishery sector showing a significant stock price reduction. This reduction is followed by stock return reduction. Stock return is one of the most important consideration factor for investor. The stock return reduction on fishery subsector can be seen on figure 1 .

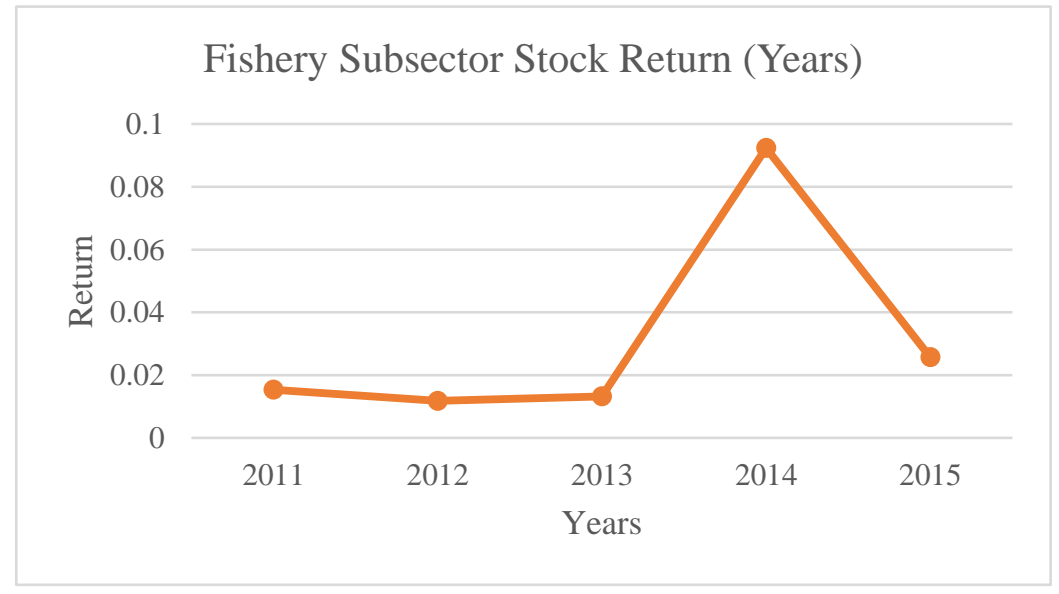

Figure 1 Fishery subsector stock return

The stock return of fishery subsector has a sharp reduction during 2014-2015 period (Figure 1). Stock return is one of the most important consideration factor for investor. The stock return reduction on plantation and fishery subsector 
might influence the investor's decision. This situation happens because of most of the Indonesian fishery companies failed to raise it stock price. There are three Indonesian fishery companies that are listed in Indonesia Composite Index, these companies are Centra Proteinprima (CPRO), Dharma Samudera Fishing (DSFI), and Inti Agri Resources (IIKP). The stock return for each companies is less atractive on 2011-2014 period where the stock return are mostly low compared to 2015 period where the stock returns are more fluctuative (Figure 2).

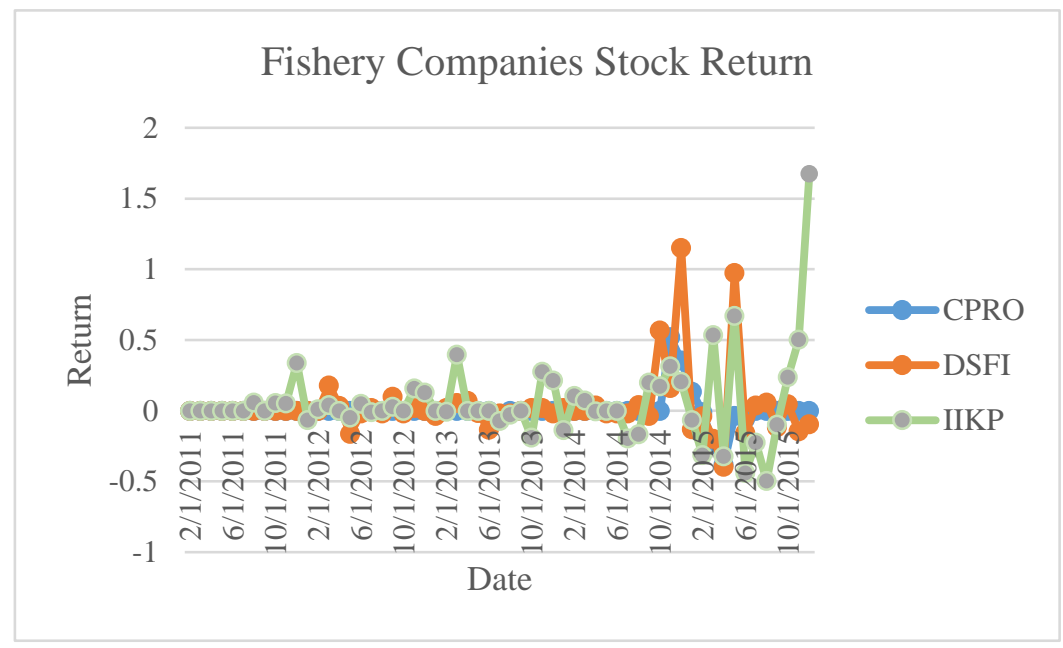

Figure 2 Fishery companies stock return

The condition of fishery subsector might scared investor to invest. Therefore the factor that affect stock return in fishery subsector are needed to know, so the investor has a good picture about consideration when investing in fishery subsector. One of the posible way to examine the factor that afect stock return is by using fundamental analisys. The fundamental analysis is

The purpose of this research is to examine the relationship between the companies financial peformance and stock return. The companies financial peformance are measured by finacial ratio such as Current Ratio, Debt to Equity Ratio (DER), and Return on Equity (ROE) who are represent liquidity, solvency, and companies profitability. Other factor that has to be measured is Economic Value Added (EVA), by calculating EVA we will find out how much the companies are able to create a value added to their investor. One of the macroeconomic factor that expected to have significant effect on stock return is exchange rate. The activiti of plantation and fishery industries are circle around export and import, therefore exchange rate are expected to be macroeconmic factor that could affect stock return.

\subsection{Financial Ratio}

\section{LITERATURE REVIEW}

Financial ratio is a relative magnitude of two selected numerical values taken from financial statement. Financial ratio often used to evaluate overall financial condition of a company or organization. In general financial ratio used to evaluate the ability of one company to make a profit and the ability to fulfil their obligation. A company with a good financial ratio's value is a reasonable target for investor to get return. The connection between financial ratio and stock return was shown in Artha's research in 2014 that state there is a significant result between some of financial ratio's instrument and stock return in agriculture sector.

\subsection{Economic Value Added}

Economic Value Added is a measure of the success of the company's management to increase the value added (value added) for the company. The assumption is that if the performance of good management / effective (as seen from the magnitude of the added value given), it will be reflected in an increase in the company's stock price. EVA can also be interpreted as the value attributed by management to the shareholders for a particular year. EVA profit reflects the residue left after the cost of the entire capital including equity capital deductible. It can be concluded that the Economic Value Added (EVA) is an operating profit after tax, minus the cost of capital used to assess the performance of the company with due regard to a fair expectations of the shareholders and creditors. EVA was proven to have a significant relation with stock return according to Hidayat's research in 2011.

\subsection{Exchange rate}

Exchange rate is a financial instrument that attract both local investor and foreign investor. According to Utami's research in 2015 there was a significant relationship between exchange rate and stock return. 


\section{METHODOLOGY}

This study used a descriptive approach and verification using secondary data. Descriptive approach used to give an overview of the company's financial condition and ability to provide added value for investors through financial ratios and Economic Value Added (EVA), while the verification used to describe statistical data that shows the relationship between financial ratios, EVA, and the exchange rate on stock returns by using a mathematical model.

The object of this study are the entire population of listed fishery companies in Indoensia Composite Index. The list of the companies in this study are shown in the Table 1.

Table 1 The fishery companies in Indonesia Composite Index

\begin{tabular}{r|l|l|l}
\hline No & Companies Name & Code & IPO's Date \\
\hline 1 & Central Proteinprima & CPRO & 28 November 2006 \\
2 & Dharma Samudra Fishing & DSFI & 24 March 2000 \\
3 & Inti Agri Resources & IIKP & 20 October 2002 \\
\hline
\end{tabular}

\subsection{Research Variable}

The independent variables in this study using financial ratios, EVA, and macroeconomic factors such as exchange rate, while the dependent variable in this study is the stock return. To assess the performance of companies, this study used financial ratios that can measure the level of liquidity, solvency, and profitability. The list of financial ratio that used in this study can be seen in table 2 .

Table 2 Financial ratio in research

\begin{tabular}{l|l|l|l}
\hline No & Name & Type & Formula \\
\hline 1 & Current ratio & Liquidity & Current ratio = Current Asset / Current Liability \\
2 & Deb to Equity Ratio (DER) & Solvency & DER = Total Debt / Total Equity \\
3 & Return on Equity (ROE) & Profitability & ROE = (Net Income / Total Equity) x100\% \\
\hline
\end{tabular}
formula:

EVA is used to calculate the value added produced by the company for investors. EVA value obtained by using the

$$
\text { EVA }=\text { NOPAT }-(\text { WACC } x \text { Invested Capital })
$$

Where:

NOPAT $\quad=$ Sales revenue - Operating cost - Tax

Invested Capital $\quad=$ Total Asset - Current Liability

WACC = Capital Asset Pricing Model

The calculation of the WACC can be made through a Capital Asset Pricing Model (Beninga 2014). The calculation of the WACC in the study carried out by the formula:

$$
\frac{\text { Debt }}{\text { Total Pasiva }} \times(\text { Cost of Debt })(1-\mathrm{T})+\frac{\text { Equity }}{\text { Total Pasiva }} \times(\text { Cost of Equity })
$$

Where:

$$
\begin{array}{ll}
\text { Cost of Debt } & =\frac{\text { Net Interest Paid }}{(\text { Average net debt })} \\
\text { Cost of Equity } & =\mathrm{rf}+\beta[\mathrm{E}(\mathrm{rm})-\mathrm{rf}] \\
\mathrm{T} & =\text { Tax Rate }
\end{array}
$$

Exchange rate is the price of one unit of foreign currency in the domestic currency or it can also be said the price of the domestic currency against foreign currencies. The more stable exchange rate of a country's currency against the currencies of other countries will show the fundamental strength of the country's economy. Exchange rate or the exchange rate used in this study is Rupiah (Rp) compared to the US Dollar (US \$).

The dependent variable in this study is the stock return. To calculate stock returns, the formula is:

Stock Return $=\frac{(\text { Current Stock Price }- \text { Stock Price from Previous Period })}{\text { Stock Price from Previous Period }}$ 


\subsection{Research Model}

The model in this study using panel data. Generally there are three commonly used models, namely Pooling Least Square (PLS), Fixed Effects Model (FEM), and Random Effects Model (REM). To choose the model used to do Chow Test, Test and Test Hausman Lagrange Multiplier.

Chow test is done to choose between methods PLS without dummy variables or FEM. After the Chow test conducted Lagrange Multiplier test to choose between the PLS and REM, then performed the Hausman test to choose between REM and FEM.

After a string of testing is done, the use of regression analysis is necessary to test the classical assumption that the results of this regression showed a valid relationship to meet the assumptions Unbiassed Best Linear Estimator (BLUE). As such they should be performed classical assumption of normality test, heteroskedasitas, autocorrelation, and multicolinearity.

Model equations influence of financial ratios, EVA and the exchange rate to return stock in this study are:

$$
\mathrm{R}_{\mathrm{it}}=\mathrm{a}+{ }_{\mathrm{a} 1} \mathrm{CR}_{\mathrm{it}-2}+\mathrm{a}_{2} \mathrm{DER}_{\mathrm{it}-2}+\mathrm{a}_{3} \text { ROEit }_{2}+\mathrm{a}_{4} \mathrm{EVA}_{\mathrm{it}-2}+\mathrm{a}_{5} \mathrm{KURS}+\mathrm{e}_{\mathrm{it}-2}
$$



\section{EMPIRICAL FINDING}

The model used in this study is Pooled Least Square (PLS). The model obtained after the chow test and the result shown that chi-square probability is 0.1945 , so at the confidence level $(\alpha)$ of $5 \%$, probability value is more than the $\alpha$ value. Since chi-square probability value is more than the value of $\alpha$, then the decision is accept $\mathrm{H}_{0}$ using a common effect model or Pooled Least Square (PLS).

Regression results do show there is no significant impact on the independent variables were tested in this study, both the EVA, current ratio, DER, ROE, and the exchange rate has no effects on stock return. The result of regression can be seen at Table 3 .

Table 3 Regression Result

\begin{tabular}{c|c|c|c|c}
\hline Variable & Coefficient & Std. Error & t-Statistic & Prob. \\
\hline C & -0.356772 & 0.445971 & -0.799988 & 0.4273 \\
EVA & 8.7400009 & 4.1000008 & 0.212964 & 0.8322 \\
CR & -0.036709 & 0.075083 & -0.488913 & 0.6269 \\
DER & -0.000546 & 0.004424 & -0.123374 & 0.9023 \\
ROE & 2.1900006 & 0.000684 & 0.003204 & 0.9975 \\
KURS & 4.2000005 & 3.8900005 & 1.078621 & 0.2865 \\
\hline
\end{tabular}

This research was conducted at the level of $(\alpha)$ of $5 \%$, which means the level of errors or mistakes tolerated in this study was 5\%. Based on Table 3 known that EVA has a probability value of 0.8322 , the current ratio has a probability of 0.6269 , DER has a probability of 0.9023 , ROE has a probability of 0.9975 , and the exchange rate has a probability of 0.2865 . A probability value all independent variables in this study surpass the level of confidence $(\alpha)$ which is set so that all independent variables do not have a significant effect on stock returns.

R-squared value is based on panel data regression that has been done is 0.061 , which means the variables that determine the value of stock returns in this study is explained by only $6.1 \%$ of the EVA, current ratio, DER, ROE, and the exchange rate variables, and the rest are $94,8 \%$ other variables outside the research that can explain stock returns.

Current ratio variable has probability of 0.6269 at the confidence level $(\alpha)$ of $5 \%$. The value indicates that the current ratio does not have a significant effect on stock returns. Current ratio coefficient value is -0.0367 which indicates that the current ratio and stock returns have a negative correlation. This is contrary to the hypothesis where the current ratio is a measure of a company's ability to settle its current liabilities, so the company has a good current ratio value is a company that liquid that can give effect to the stock returns in view of fundamentalists. The results of this study are not consistent with Prihatini (2009) where the current ratio has a significant influence and positive impact on stock returns, but the results 
of this study are consistent with the results of Aditya and Isnurhadi (2013) and Anggraeni (2010) which states that the current ratio does not has a significant effect on stock returns.

DER variable has a probability value of 0.9023 on the confidencel level $(\alpha)$ of $5 \%$. In this study DER does not have a significant effect on stock returns. DER coefficient value is -0.000546 it shows the relationship between DER with stock return is negative relationship, so the higher the value, the smaller DER stock returns produced by the company. The results of this study contradict the initial hypothesis where the DER has a significant impact on stock returns. DER is the ratio between the company's debt and capital, that means the higher the value of DER showed that the company had a high debt that affect the company's ability to make a profit, the company will have the tendency to pay its debts in advance so it will affect stock returns. The results of this study are not consistent with Prihantini (2009), Artha et al (2014), Jauhari (2003), and Tineke (2007) which states that the DER has a significant and negative effect on stock returns. Another study supports the results of this study are Nathael (2008), Aditya and Isnurhadi (2013), and Anggraeni (2010) which states that there is no significant relationship between DER with stock returns.

ROE in this study has a probability of 0.9975 at confidence level $(\alpha)$ of $5 \%$. These results indicate that there is no influence between ROE to return stock in the plantation subsector. ROE coefficient value is 2.19 which indicates the direction a positive influence between ROE stock return. The results of this study are not in line with the initial hypothesis which states that the ROE has a significant effect on stock returns for ROE is an indicator of the profitability of the company, the higher the ROE means net income of companies higher, other than that ROE can also be used as a benchmark to determine the ability of the company in utilizing venture capital owned, so the higher the ROE value means the better the company's ability to manage capital owned which will affect stock returns. The results of this study are not consistent with Jauhari (2003) and Aditya and Isnurhadi (2013) which states that the ROE has a significant influence in a positive direction on stock returns, but the results of this research was supported by research Anggraeni (2010) which states that ROE has significant relationship with stock return.

EVA variable has 0.8322 probability value and confidence level $(\alpha)$ of $5 \%$, so in this study EVA does not have a significant effect on stock returns. EVA coefficient is -0.036 , which means the direction of EVA influence on stock return is negative. These results do not match initial denganhipotesis stating that the EVA have a positive influence on stock returns because EVA is the added value created by the company to investors, so that the higher the EVA value indicates the company has managed to create added value so that it will affect stock returns. The results of this study are not consistent with Wijaya and Tjun (2009), Tineke (2007), Hidayat and Setyaningsih (2011), and Mandilas et al stated that EVA has a significant effect on stock returns. Another study states that EVA does not have a significant effect on stock returns made by Arief et al (2013), Anggraeni (2010), Trisnawati (2009), and Sunardi (2010).

A probability value for exchange rate in this study was 0.2865 on the confidence level $(\alpha)$ of $5 \%$. This shows there is no significant influence of the exchange rate with stock returns. Value exchange rate coefficient is 4.2 , which means the exchange rate relationship with stock returns have a positive direction. These results are not in line with the initial hypothesis in which the exchange rate has a significant impact on stock returns because of the activities in the plantation subsector is heavily influenced by exports and imports so that the exchange rate is one of the macroeconomic factors that may affect the company pendapatn. The exchange rate is increasingly strengthened against the US Dollar is shown by the narrower exchange rate, so that the smaller the rate of the profits of companies in the plantation subsector increasingly large and will affect stock return, thus the direction of exchange rate relationship with stock returns should be negative. The results of this study are not consistent with research Sodhikin (2007), Tambunan and Riantani (2013), Triayuningsih (2003), and Artha et al (2014) which states that the exchange rate has a significant effect on stock returns, but the results of this study are supported by Wiajaya (2008) stating that the exchange rate does not have a significant effect on stock returns.

\section{CONCLUSION}

There are no significant effects between current ratio, DER, ROE, EVA, exchange rate and stock return. For investors who will invest in the fishery sector, the company's performance and macroeconomic factors need not be a primary consideration. Based on the results of this study fundamental factors the company has no significant impact on the stock return.

\section{REFERENCES}

- Achsani A, Kurniadi A, Sasongko H. 2013. Kinerja Keuangan Berbasis Penciptaan Nilai, Faktor Makroekonomi dan Pengaruhnya Terhadap Return Saham Sektor Pertanian. Jurnal Akuntansi dan Keuangan 15(2): 63-74.

- Achsani A, Sasongko H, Artha D. 2014. Analisis Fundamental, Teknikal, dan Makro Ekonmi Harga Saham Sektor Pertanian. Jurnal Manajemen dan Kewirausahaan 16(2): 175-184.

- Aditya K, Isnurhadi. 2013. Analisis Pengaruh Rasio Lancar, Rasio Perputaran Aktiva, Debt to Equity, Return on Equity, dan Earning per Share terhadap Return Saham Perusahaan Sektor Infrastruktur yang Terdaftar di Bursa Efek Indonesia Periode 2007-2011. Jurnal Manajemen dan Bisnis Sriwijaya 11(4): 83-99.

- Anggraeni A. 2010. Pengaruh Rasio Likuiditas, Aktivitas, Profitabilitas, Leverage, dan Economic Value Added Terhadap Return Saham pada Saham Food and Beverages di Bursa Efek Indonesia. Jurnal Ekonomi 1(2): 69-85. 
- $\quad$ Beninga S. 2014. Financial Modeling $4^{\text {th }}$ Edition. London (EN): The MIT Press

- Fathoni N, Rusliati E. 2011. Inflasi, Suku Bunga Deposito, dan Return Pasar Terhadap Return Saham Pada Industri Barang Konsumsi yang Terdaftar di BEI 2006-2009. Jurnal Bisnis dan Akuntansi 13(2): 126-143.

- Hidayat A, Setyaningsih S. 2011. Pengaruh Economic Value Added, Market Share, Earning, dan Net Cash Flow terhadap Return Saham (Studi Pada Perusahaan Manufaktur Jenis Consumer Good di Bursa Efek Indonesia. Jurnal Wira Ekonomi Mikroskill 1(2): 79-87.

- Jauhari R. 2003. Analisis Pengaruh Debt to Equity, Price Book Value, Price to Earning Ratio, dan Devident Payout Ratio terhadap Return Saham (Studi Kasus Saham LQ45 di BEJ). [Tesis]. Semarang (ID): Universitas Diponogoro.

- Mandilas A, Floropoulos I, Angelakis G. 2009. EVA Reconsidered for the Greek Capital Market. European Research Studies 12(2): 136-149.

- Nathael N. 2008. Analisis Faktor-Faktor yang Mempengaruhi Return Saham. [Tesis]. Semarang (ID): Universitas Diponogoro

- Prihantini R. 2009. Analisis Pengaruh Inflasi, Nilai tukar, ROA, DER, dan CR terhdap Return Saham. [Tesis]. Semarang (ID): Universitas Diponogoro Semarang.

- Sodhikin A. 2007. Variabel Makroekonomi yang Memengaruhi Return Saham di BEJ. Jurnal Manajemen 6(2): $25-41$

- Sunardi H. 2010. Pengaruh Penilaian Kinerja dengan ROI dan EVA terhadap Return Saham pada Perusahaan yang Tergabung dalam Indeks LQ45 di Bursa Efek Indonesia. Jurnal Akuntansi 2(1): 70-92.

- Tambunan M, Riantani S. 2013. Analisis Pengaruh Makroekonomi dan Indeks Global Terhdap Return Saham. Seminar Nasional Taknologi Informasi dan Komunikasi Terapan 2013 (Semantik 2013).

- $\quad$ Tineke R. 2007. Analisis Pengaruh Economic Value Added dan Faktor-Faktor Fundamental Perusahaan terhadap Return Saham. [Tesis]. Semarang (ID): Universitas Diponogoro.

- Triayuningsih R. 2003. Analisis Pengaruh Kinerja Keuangan Perushaan dan Faktor Ekonomi Makro Terhadap Return Saham Perusahaan Industri Manufaktur di BEJ 1999-2001. [Tesis]. Semarang (ID): Universitas Diponogoro.

- Trisnawati I. 2009. Pengaruh Economic Value Added, Arus Kas Operasi, Residual Income, Earnings, Operating Leverage, dan Market Value Added Terhadap Return Saham. Jurnal Bisnis dan Akuntansi 11(1): 89-107

- Wijaya H, Tjun L. 2009. Pengaruh Economic Value Added Terhadap Tingkat Pengembalian Saham pada Perusahaan yang Tergabung dalam LQ45. Jurnal Akuntansi 1(2): 180-200

- Wijaya S. 2008. Pengaruh Faktor-Faktor Makroekonomi dan Return IHSG terhadap Return Saham Sektor Usaha Primer. [Tesis]. Bogor (ID): Institut Pertanian Bogor.

- Young S, David and Stephen F. O’Byrne. 2001. Economic Value Added and Value Based Management : A Practical Guide to Implementation. New York (US): Mc Graw-Hill. 